DOI https://doi.org/10.18551/rjoas.2017-12.32

\title{
FINANCIAL AND ECONOMIC APPRAISAL OF IRRIGATED RICE ENTERPRISE: CAPITAL BUDGETING APPROACH
}

\author{
Coker Ayodeji Alexander Ajibola*, Jirgi Abigail John, Mohammed Usman Shaba, \\ Adebayo Cornelius Owoniyi, Tuedogheye Jeremiah \\ Department of Agricultural Economics and Extension Technology, School of Agriculture and \\ Agricultural Technology, Federal University of Technology, Minna, Nigeria \\ ${ }^{*}$ E-mail: ayodejicoker@futminna.edu.ng
}

\begin{abstract}
The need to ensure the viability and sustainability of agricultural investments in Nigeria, particularly in Niger State, juxtaposed with the national agricultural policy goal of food security attainment, demands that proposed agricultural investments are well appraised and designed. This article therefore determined the financial and economic viability and sustainability of irrigated rice enterprise in Kawo Irrigation Site in Kotangora, Niger State, Nigeria. The methodology was based on the economic theory of utility maximization cum profit motive. To achieve these objectives, the capital budgeting tools of discounted cash flow, net present value, financial and economic internal rate of returns were used. The results showed that the estimated NPVs were positive, while the IRR were higher than the opportunity cost of capital under the two scenarios considered; implying that irrigated rice enterprise will be financially viable to enhance the net returns to farmers, while generating positive externalities to the agriculture sector of Niger State and Nigeria in general. The sensitive analysis revealed that the financial and economic internal rate of returns were more sensitive to changes in irrigated rice yields under both scenarios analysed. The study concluded that irrigated rice production will be financially and economically profitable and sustainable in the site and thus, recommended investment on irrigated rice intensification, premised on the adoption of improved agricultural inputs and associated technologies.
\end{abstract}

\section{KEY WORDS}

Agricultural investment, financial and economic viabilities, discounted cash flow, net present value, financial internal rate of return, economic internal rate of return, rice, food security.

Nigeria's rice consumption has risen tremendously since the mid-1970s (Akande, 2003), with the current demand and supply gap, put at 4 million, largely attributed to inadequate supply chain integration (Federal Ministry of Agriculture and Rural Development, 2016). The Federal Ministry of Agriculture and Rural Development (2015) and Bamidele et al. (2010) noted that rice is one of the food security crops grown in large quantities which constitute the main staple food items of the populace and can guarantee the nation's food security. FMARD (2014) puts the farming households involved in rice cultivation in Nigeria in 2013 at 22 per cent of the national farming population, which was an increase of 13 per cent over 2013. Expectedly, the estimated acreage cultivated increased from 2.2 million hectares to about 2.6 million hectares within same period. The average rice paddy obtained per household stands at $1.9 \mathrm{mt}$ while national output was 5.9 million $\mathrm{mt}$ in 2013 , representing 6.2 million $\mathrm{mt}$ in standard grain equivalent. In Niger State, estimated area cultivated for rice during the wet season in 2013 was 264,004 hectares with total output of 824,486 metric tonnes.

In-spite of these efforts, Gyimah-Brempong, Johnson and Takeshima (2016) affirmed that paddy yields in Nigeria are among the lowest in the African region and well below other developing countries in Asia and Latin America. The returns on investment have also been low, arising from the low output per hectare and price fluctuation. From the demand angle, the average Nigerian consumes $24.8 \mathrm{~kg}$ of rice per year, representing 9 per cent of annual caloric intake (International Rice Research Institute, 2001). Recently however, Food and Agriculture Organization (2016) puts the global per capita consumption of rice at $50 \mathrm{~kg}$ per 
annum. Meanwhile, the International Food Research Institute (2016) noted that rice has become one of the leading food staples in Nigeria, surpassing cassava in food expenditures. The organisation further posited that consumption had increased faster than production, resulting in a growing dependency on import and that by 2014; about half of the rice consumed in Nigeria was imported. Not unexpected, the structure of Nigeria's rice economy has been highly import dependent, with majority of Nigerians enmeshed in the burden of food insecurity, poverty, inequality and unemployment. Meanwhile, varying levels of outcomes have been noted across seasons, agro-ecological zones and even among actors and genders, while from the economic point of view, little is known in quantitative and value terms of the economic contributions of the rice industry to economy, though, without prejudice to the outcomes of the financial and economic analysis undertaken by the donor organisations on projects identified for support, which in most cases are restricted. Thus, given the low productivity, low returns on investment and dependence on import on one hand, government and market failures on the other hand, it has become imperative to undertake the financial and economic analysis of rice enterprise in Nigeria, with a view to ascertaining the benefits of rice to the farmer and society. Aside these, the practical application of the capital budgeting tools to financial and economic analysis, though, theoretically documented, have been associated with numerous practical difficulties in application by local and national planning officers, agricultural economists, undergraduate and graduate students and other relevant specialists involved in agricultural project preparation. This article provides the guidelines and easy to follow practical application of the capital budgeting tool of DCF to financial and economic analyses. Specifically, this article determined the financial and economic viability and sustainability of the proposed irrigated rice enterprise under Kawo Irrigation Site in Kotangora, Niger State. The study hypothesized that it is not worthwhile investing in irrigated rice enterprise in the site.

\section{LITERATURE REVIEW}

The conventional investment appraisal theory of the firm has been severally deployed for the analysis of intended project investments. Conventionally, investment appraisals have been premised on several theories, such as, stakeholders' theory, agency theory, stewardship theory and resource dependence theory (Kalyebara and Islam, 2014). While the stakeholder theory focused on the relationship between the organisation and its stakeholders, factoring in the need to maximise stakeholders profit motive, the agency theory narrows down to the contract between the organisations and managers. The stewardship theory on the other hand is premised on the non-economic motive or social consideration in investment undertakings, while the resource dependence theory hinges on the organisation's ability to control external resources. These theories naturally provide the requisite setting and justification for project investment appraisal premised on the duality of profit and social consideration. This background naturally provides the setting for the discussion of the various investment appraisal approaches.

Kalyebara and Islam (2014) posited that the two key decisions made by entrepreneurs are investment decisions (bordering on capital budgeting or investment appraisal) and financial decisions, which ascertains how the chosen investment should be funded (either by equity or debt or a combination of the two). Ross et al. (2011) affirmed the existence of various capital budgeting techniques amenable for investment appraisal. These according to the researchers include the discounted cash flow (DCF) and the non-discounted cash flow (NDCF) approaches. The DCF takes cognisance of the time value of money and associated financial and business risks. This approach comprises the net present value (NPV), internal rate of return (IRR) and the profitability index (PI). The NDCF on the other hand ignores the time value of money and hence, fails to factor in financial and business risks. These include the payback period (PBP) and accounting rate of return (ARR). For this article, focus is on the DCF, given its inherent benefits as earlier mentioned and the unique Nigeria setting (associated with high inflation and business risks) in which project investment is being analysed. 
Seitz and Ellison (1999) posited that the dominant traditional investment appraisal method utilises the net present value (NPV) to measure the performance of capital projects. According to the source, NPV is determined by discounting future net cash flows using a riskadjusted discount rate to arrive at the present value and then deducting the initial investment from the sum of the present values. Kalyebara and Islam (2014) equated capital budgeting with investment decision making and investment appraisal. In this realm, capital investment was defined as the decisions made to allocate capital resources most efficiently in long-term activities in the hope that aggregate further benefits exceed the initial investment so as to maximise owners' wealth. It was further noted that the cash flows are the key instrument for any business because other resources can be bought if the cash inflows exceed cash outflows. The article affirmed that investment projects can be evaluated to identify those that maximize the value of the enterprise by the use of net present value. A caveat was however raised that the use of NPV alone may not serve the interest of all, given that other stakeholders may be interested in other measures such as cost minimization. While some researchers have complemented the NPV with the agency cost reduction, which entailed consideration for mitigation of enterprise cost (Cui and Mak 2002; Florackis 2008; Jensen 1986); others such as Lau employed multiple approaches using accounting ratios for investment appraisal instead of the discounted measures of project worth, though without prejudice to the unique characteristics of the organisation in the e-commerce industry.

In a related development, Kalyebara and Islam (2014) defined the IRR as the rate of growth a project is expected to generate and hence, the higher the IRR, the more profitable the project. Some of the benefits of the IRR highlighted included, consideration for project risks and time value of money and the utilisation of cash flow. The weaknesses centre mainly on the net cash flow being re-invested at a rate of return equal to the IRR, duality of IRR when using an unconventional cash flow, thus leading to conflicting results and the nonseparation between mutually exclusive projects of varying sizes.

\section{METHODS OF RESEARCH}

The study was undertaken in Kawo Irrigation Site in Kotangora Local Government Area of Niger State, south bank of the Kotangora River, in north central, Nigeria. Niger State is located between Latitudes $8^{\circ} 22^{\prime}$ and $11^{\circ} 30^{\prime} \mathrm{N}$ and Longitudes $33^{\circ}$ and $7^{\circ} 20^{\prime} \mathrm{E}$. The State is bordered to the North by Zamfara State, West by Kebbi State, South by Kogi State, South West by Kwara State, North East by Kaduna State and South East by FCT. The State also shares an international border with Niger Republic at Babanna. Kawo is located in the subhumid climate zone of the tropics, with an average annual rainfall of 1,200 $\mathrm{mm}$. Temperature ranges between $22^{\circ} \mathrm{C}$ and $38^{\circ} \mathrm{C}$. The soil types are of two types, namely the $\mathrm{Ku}$ soil and $\mathrm{Ya}$ soil. The former is associated with little erosion hazards, while the latter has the advantage of high water retention capacity. The State has an estimated population of 5,278,415 as at 2016 (Salaudeen, 2017). Majority (85\%) of the populace are involved in farming. The key crops grown are rice, yam, sorghum, maize, millet, groundnut and cowpea. Kawo also supports dry season farming, covering crops like rice, vegetables and sugar cane.

A random selection of 40 farmers was undertaken within the irrigation site through the assistance of the lead farmer, given the absence of a farmer frame. Farmers selected were all involved in rice. The study utilised both primary and secondary data. Primary data solicited covered socio-economic variables and input output variables on farmers' farming operations. Relevant data were also sourced from the Niger State Bureau of Statistics, Department of Crop Production and Department of Agricultural Economics and Extension Technology of the Federal University of Technology, Minna, National Planning Commission, Nigeria Customs Service and the Nigeria Internal Revenue Service. Vital data and methodological approaches were also obtained from past and on-going donor projects' appraisal documents and practice of packages of on-going donor projects and programmes. International prices were obtained from FAO and Index mundi web sites.

The analytical framework for this article was the conventional investment appraisal theory of the firm, which is premised on the discounted measures of project worth in the 
estimation of the characterizing production parameters in the analysed irrigation site. In this direction, the NPV and IRR were utilised to analyse the primary and secondary data utilised.

The main worksheets utilised included the price worksheet; the Input utilization per worksheet, the production pattern worksheet and the cash flow. The production pattern worksheet is linked with the input utilization and prices worksheets to develop and project the operating costs for 25 years. The subheads in these work sheets are the Investment costs, including fixed costs of buildings and equipments, tools, farm improvements, irrigation facilities, canals etc; overheads etc; and the operating costs, which comprises seeds, labour, fertilizers, etc. These form the building blocks for cash flow worksheet. The financial prices were converted to economic prices using best practices detailed by Gittinger (1984) and the Asian Development Bank (2017).

The computation of the financial and economic rates of returns for this article was predicated on the following assumptions:

1. Domestic prices were used to assess the values of inputs and outputs under financial analysis, while international prices were adjusted to obtain the economic costs;

2. The investment cost on irrigation infrastructure was based on irrigation investments on sites with similar features; that is, centralised irrigation based on gravity is assumed under this article;

3. The investment is expected to result in between 50 and 55 per cent increase in yield of rice, arising from adoption of improved technologies and agronomic practices;

4. It is assumed that beneficiaries will purchase and sell their inputs and outputs at prevailing market prices;

5. Beneficiaries investments will come from borrowed fund and donor intervention;

6. The market prices are not too different from economic prices due to the little disparity between official and parallel markets;

7. Cost of irrigation water was put at \$US 41 during dry season and \$US13 under supplementary irrigation;

8. The net present value (NPV) is computed at $12 \%$ interest rate. The financial and economic internal rates of returns (FIRR and EIRR) are estimated for 25 years, being the lifespan of the proposed irrigation investment.

9. Lending rates to participants is at the existing 9 per cent Central Bank of Nigeria rate under the Anchor Borrowers' Programme, while borrowed fund is repaid in equal instalments;

10. Analysis was undertaken at constant prices, given the need to obviate the effect of inflation;

11. Capital depreciation was not considered given that annual provisions were made for purchases and replacement of equipment; and

12. Analysis was based on one hectare rice production enterprise in line with previous appraisal undertaken in Nigeria.

Model Specification. The NPV was used to measure the performance of the Kawo Irrigation Site Investment in irrigated rice production. The NPV was determined by discounting future net cash flows using a risk-adjusted discount rate to arrive at the present value and then deducting the initial

investment from the sum of the present values. These were achieved through linked excel templates as earlier mentioned. A positive NPV signifies the profitability of the investment and hence that the investment should be undertaken. The operational model is detailed in equation 1.

$$
\mathrm{NPV}=\sum_{t=0}^{t} \frac{B_{t}-C_{t}}{(1+r)^{t}}
$$

Where: NPV $=$ Net Present Value; $B_{t}=$ Benefit accruing in Period $t ; C_{t}=$ Cost incurred in Period $t ; r=$ Discount rate or Interest rate.

For this article, both the financial and economic rates of returns were derived, as they related to the participating farmers and the society as a whole. This model was used given its 
global application and simplicity. Researchers like Hendricks (1980); Anderson (1982) and Mukherjee (1988) affirmed the popularity of the IRR. The decision rule is that when the IRR is equal to or greater than the cost of capital after tax, the project is accepted; however, with respect to mutually exclusive projects, the project with the higher IRR is accepted (Kalyebara and Islam, 2014).

$$
\mathrm{IRR}=\frac{R_{1}}{(1+r)^{1}}+\frac{R_{2}}{(1+r)^{2}}+\frac{R_{3}}{(1+r)^{3}}+\frac{R_{4}}{(1+r)^{4}}+\ldots \ldots \ldots \ldots \ldots \ldots \ldots \frac{R_{n}}{(1+r)^{n}}
$$

Where: $r=$ Discount rate or Interest rate; $R_{1}, R_{2}, R_{3}, R_{4} \ldots . . R_{n}=$ Net benefit for number of years; $n=$ Number of years.

\section{RESULTS AND DISCUSSION}

Financial Analysis. The results of the financial analysis as detailed in table 1 show that the NPV and IRR under sole irrigation cropping in Kawo irrigation site would be $\mathbb{N 1}, 413,839$ and 36 per cent compared to the $\mathrm{N1}, 362,507$ and 33 per cent estimated for supplementary irrigation under same site. These results imply that rice enterprise will be profitable under both scenarios if the opportunity cost of capital is than the IRR, else, it may be better to save the money with the bank. Further insight into the results reveal that sole irrigated rice enterprise will be more profitable, given the higher NPV and IRR. Numerous studies have established higher rice yields under irrigation compared to other farming scenarios (International Plant Nutrition Institute). The sensitivity analysis as detailed in table 2, revealed a marginal change in IRR from 35 per cent to 36 per cent, when the cost of irrigation water was increased and decreased by 10 per cent respectively. However, with 3 per cent variation in rice yields, IRR fluctuated between 38 per cent and 34 per cent with respect to yield increase and decrease respectively. The results under supplementary irrigation are as provided in the table 1.

Table 1 - Financial analysis results

\begin{tabular}{|c|c|c|c|c|c|c|c|}
\hline \multirow[t]{2}{*}{ Cropping Scenario } & $\begin{array}{c}\text { Total } \\
\text { Investment } \\
\text { Cost for } 40 \\
\text { Hectare }\end{array}$ & $\begin{array}{l}\text { Investmen } \\
\text { t Cost per } \\
\text { Hectare }\end{array}$ & $\begin{array}{l}\text { Operation } \\
\text { al Cost per } \\
\text { Hectare }\end{array}$ & $\begin{array}{c}\text { Increment } \\
\text { al Benefit } \\
\text { per } \\
\text { Hectare }\end{array}$ & \multirow[t]{2}{*}{$\begin{array}{l}\text { Increment } \\
\text { al Benefit } \\
\text { for } 40 \\
\text { hectares } \\
\text { (A) }\end{array}$} & $\begin{array}{c}\text { NPV at } \\
12 \%\end{array}$ & $\begin{array}{c}\text { EIR } \\
\mathrm{R}\end{array}$ \\
\hline & $(\mathrm{A})$ & $(\mathbb{A})$ & $(\mathrm{A})$ & $(\mathbb{N})$ & & $(\mathbb{A})$ & $(\%)$ \\
\hline Irrigated & $\begin{array}{c}700,000,00 \\
0\end{array}$ & $\begin{array}{c}17.500,00 \\
0\end{array}$ & 86,124 & 392,483 & $\begin{array}{c}15,699,32 \\
0\end{array}$ & $\begin{array}{c}1,413,83 \\
9\end{array}$ & 36 \\
\hline $\begin{array}{l}\text { Supplementary } \\
\text { Irrigation }\end{array}$ & $\begin{array}{c}700,000,00 \\
0\end{array}$ & $\begin{array}{c}17.500,00 \\
0\end{array}$ & 76,124 & 392,483 & $\begin{array}{c}15,699,32 \\
0\end{array}$ & $\begin{array}{c}1,362,50 \\
7\end{array}$ & 33 \\
\hline
\end{tabular}

Source: Extracted from financial analysis cash flow.

Table 2 - Sensitivity analysis results (Financial)

\begin{tabular}{|c|c|c|c|c|c|}
\hline \multirow{2}{*}{ Cropping Scenarios } & Base Case & \multicolumn{2}{|c|}{ Change in cost of Irrigation water } & \multicolumn{2}{c|}{ Change in Crop productivity } \\
\cline { 2 - 6 } & Initial IRR & $10 \%$ & $-10 \%$ & $5 \%$ & $-5 \%$ \\
\hline Irrigated & 36 & 35 & 36 & 38 & 33 \\
\hline Supplementary Irrigation & 33 & 33 & 33 & 35 & 32 \\
\hline
\end{tabular}

Source: Extracted from financial analysis cash flow.

Economic Analysis. Table 3 detail the outcome of the economic analysis undertaken on the feasibility of irrigated rice enterprise in Kawo irrigation site. The results show positive NPVs under the two scenarios analysed, while IRRs of 36 per cent and 34 per cent were obtained under the sole irrigated and supplementary irrigation respectively. The results imply that the proposed irrigated rice enterprise will be viable in the site under both scenarios, in so far as the opportunity cost of capital is less than the IRR. As obtained under the financial analysis, rice enterprise was more profitable under the irrigated scenario. In terms of incremental benefits, estimated $\$ 16.96$ million will accrue to the society as a whole, if this 
investment is undertaken. As regards the results of the sensitivity analysis (Table 4), changes in the cost of irrigation water by 10 per cent witnessed no changes in IRR under the irrigated and supplementary irrigation. On the other hand, with 3 per cent variation in yield, IRR fluctuated between 32 per cent and 36 per cent for yield increase and decrease respectively.

Table 3 - Economic analysis results

\begin{tabular}{|c|c|c|c|c|c|c|c|}
\hline \multirow[t]{2}{*}{ ng Scenario } & $\begin{array}{c}\text { Estimated } \\
\text { Investment } \\
\text { Cost for } 40 \\
\text { Hectare }\end{array}$ & $\begin{array}{c}\text { Investmen } \\
\text { t Cost per } \\
\text { Hectare }\end{array}$ & $\begin{array}{l}\text { Operationa } \\
\text { I Cost per } \\
\text { Hectare }\end{array}$ & $\begin{array}{c}\text { Increment } \\
\text { al Benefit } \\
\text { per } \\
\text { Hectare }\end{array}$ & \multirow[t]{2}{*}{$\begin{array}{l}\text { Increment } \\
\text { al Benefit } \\
\text { for } 40 \\
\text { hectares } \\
\text { (A) }\end{array}$} & $\begin{array}{l}\text { NPV at } \\
12 \%\end{array}$ & $\begin{array}{c}\text { EIR } \\
\mathrm{R}\end{array}$ \\
\hline & (A) & (A) & $(\mathrm{N})$ & (A) & & (A) & $(\%)$ \\
\hline Irrigated & $\begin{array}{c}700,000,00 \\
0\end{array}$ & $\begin{array}{c}17.500,00 \\
0\end{array}$ & 120,856 & 424,106 & $\begin{array}{c}16,964,16 \\
0\end{array}$ & $\begin{array}{c}1,538,69 \\
6\end{array}$ & 36 \\
\hline $\begin{array}{l}\text { Supplementary } \\
\text { irrigation }\end{array}$ & $\begin{array}{c}700,000,00 \\
0\end{array}$ & $\begin{array}{c}17.500,00 \\
0\end{array}$ & 110,856 & 424,106 & $\begin{array}{c}16,964,16 \\
0\end{array}$ & $\begin{array}{c}1,488,18 \\
1\end{array}$ & 34 \\
\hline
\end{tabular}

Source: Extracted from economic analysis cash flow.

Table 4 - Sensitivity analysis results (Economic)

\begin{tabular}{|c|c|c|c|c|c|}
\hline \multirow{2}{*}{ Cropping Scenario } & Base Case & \multicolumn{2}{c|}{ Change in price of Irrigation water } & \multicolumn{2}{c|}{ Change in Yield } \\
\cline { 2 - 6 } & Initial IRR & $20 \%$ & $-20 \%$ & $5 \%$ & $-5 \%$ \\
\hline Irrigation & 36 & 36 & 36 & 38 & 34 \\
\hline Supplementary Irrigation & 34 & 34 & 34 & 36 & 32 \\
\hline & \multicolumn{2}{r}{ Source: Extracted from economic analysis cash flow } \\
\hline
\end{tabular}

Arising from the aforementioned results, the null hypothesis of this study which indicates that rice enterprise is not viable in Kawo site is rejected in favour of the alternate hypothesis, given the positive NPVs and IRR values greater than the existing rates of borrowing.

\section{CONCLUSION AND RECOMMENDATIONS}

Arising from the outcome of the study, it is concluded that the proposed rice enterprise under irrigation is expected to be financially viable to the extent that it will increase the net financial benefits to participants in the site, while economically, project has the ability to generate incremental benefits and net positive externalities to the agricultural sector of Niger State, Nigeria. Thus, it is recommended that irrigated rice enterprise be undertaken in the site complemented with supplementary irrigation. This is without prejudice to the regular rainfed rice cropping which had been the normal practice of targeted beneficiaries.

\section{REFERENCES}

1. Akande, T. (2003). An Overview of the Nigeria Rice Economy. Nigeria Institute of Social and Economic Research, Nigeria. United States Department of Agriculture: International Database (USPSD).

2. Andersson, B. (1988). Kapitalkostnader och avkastningskrav, Stockholm: Statens Energiverk.

3. Asian Development Bank, (2017). Guidelines for the Economic Analysis of Projects.

4. Cui, H. \& Mak, Y.T. (2002). The relationship between managerial ownership and firm performance in high R\& amp;D firms. Journal of Corporate Finance, 8, 313-336.

5. Food and Agriculture Organization of the United Nations (FAO), (2016). FAOSTAT Data (available at: http://faostat3. fao.org/browse/FB/CC/E [Accessed on 20 November, 2017].

6. Federal Ministry of Agriculture \& Rural Development, (2014). Report of the 2013 Wet Season Farm Output/Agricultural Production Survey (APS).

7. Federal Ministry of Agriculture \& Rural Development, (2016). The Agriculture Promotion Policy (2016-2020). 
8. Federal Ministry of Budget and National Planning (2017). Economic Recovery and Growth Plan (2017-2020).

9. Florackis, C. (2008) "Agency costs and corporate governance mechanisms: evidence for UK firms", International Journal of Managerial Finance, Vol. 4 Issue: 1, pp.37-59.

10. Gittinger, J.P. (1984). Economic Analysis of Agricultural Projects. Economic Development Institute, World Bank.

11. Hendricks, James A., 1983, "Capital Budgeting Practices Including Inflation Adjustments: A Survey," Managerial Planning (January-February), pp 22-28.

12. International Food Policy Research Institute, (2016). The Nigerian Rice Economy Policy Option for Transforming Production, Marketing and Trade. Edited by Gyimah-Brempong, K., Johnson, M. and Takeshima. University of Pennsylvania.

13. International Plant Nutrition Institute, (Undated). Rice Ecosystems. www.ipni.net/ppiweb/filelib.nsf/0/.../\$file/Rice\%20HB\%20p2-5.pdf. [Accessed on 15 November, 2017]

14. Jensen, M. C. (1986). Agency Cost of Free Cash Flow, Corporate Finance, and Takeovers. American Economic Review, Vol. 76, No. 2, pp. 323-329.

15. Kalyebara, B. \& Islam, S.M.N. (2014). Corporate Governance, Capital Markets and Capital Budgeting. Springler, Physica-Verlag Heidelberg.

16. management, 15(4), 15-22.

17. Mukherjee, T. K. (1988). "The capital budgeting process of large U.S. firms: an analysis of capital budgeting manuals", Managerial Finante, 14, No. 213, pp. 28-35.

18. Ross, M., (1986). Capital Budgeting Practices of Twelve Large Manufacturers. Financial Management 15 (No. 4, Winter), 15-22.

19. Salaudeen, A. (2017). Effect of Farmers' Perception of Economic Recession on their Food Security Status in Selected Local Government areas of Niger State, Nigeria. Unpublished Undergraduate Project of the Department of Agricultural Economics and Extension Technology, Federal University of Technology, Minna, Niger State, Nigeria.

20. Seitz, N. and Ellison, M. (1999). Capital Budgeting and Long Term Financing Decisions. The Dryden Series in Finance. Amazon. 